\title{
Customer Perception Towards Food Ordering Mobile Applications [FOMA] Services
}

\author{
M. Shanmugavel, B. Devamaindan
}

\begin{abstract}
This empirical study was aimed to explore the factors of food ordering mobile application (FOMA) services perception and usage among the customers in Chennai city. This research was adopted exploratory and empirical research design and structured questionnaire was used to gather the perception of users residing in Chennai city. The data collected were subjected to analysis using statistical tools such as percentage analysis, descriptive analysis, factor analysis, cluster and discriminant analysis has been applied to explore the findings. The result indicates that seven factors has been extracted out of 20 FOMA services perception variables and three cluster groups were significantly classified among the users of FOMA services. The researchers concluded that online food ordering service providers are suggested to attract more food suppliers in nook and corner of the city to attract and serve more customers in near future to meet the expected increase in the demand.
\end{abstract}

Keywords : FOMA Services, Mobile Applications, Food Industry, Customer Perception and Usage.

\section{INTRODUCTION}

The mobile application (Hereafter App or Apps) is a software which is enables the user interface on particular activities, like specific service offered from Shopping, social media, Games, and utility apps etc. in this line up, food ordering mobile app is gives the prompt interaction with the user for their food need on any places Home, Office and vacation spot etc., Cheap Chinese Mobile Phone entries and competitive offers of internet service provider enables the more youngsters in india forced to buy those technology and in this context the Food ordering Mobile Application service provider targeting the opportunity to reach the customer on their palm. The custom of society is to pride to having food from hotels now they having those feel in getting the desired food from door step delivery, the people who having no time to prepare the special and unique food from home and unwilling for get themselves to reach the hotel are preferring the FOMA services. Since the hotel direct door delivery services are charging higher on the delivery the food on designated customer and its overburden to the Restaurant

Revised Manuscript Received on December 05, 2019.

* Correspondence Author

M. Shanmugavel*, $\mathrm{PhD}$ - Rajiv Gandhi National Senior Research Fellow, Department of Commerce, School of Business and Management Studies, University of Madras, Chepauk, Chennai, Tamil Nadu - India. Email: info7shanmugavel@gmail.com

Dr. B. Devamaindan, Associate Professor, Department of Management Studies, Institute of Distance Education, University of Madras, Chepauk, Chennai, Tamil Nadu - India and hotel for delivering the food themselves due unpredictable demand. But the FOMA service enables the single widow system to deal with all those issues on both ends. The welcome offer issued by FOMA services addicts the packet money depending youngster to steal the deal. The FOMA service create the artificial demand on many case due to the consumer misunderstanding of the hotel which is cost more for a food and hesitate to reach hotel for fear of hotel charging high costing on their food. Later this FOMA service identify the hotel menu and the price tag of those menu to the customer hand with some specific discount and offer and it kindle the consumer to experience the hotel menu soon. Meanwhile lots of job opportunity developed due to this platform and hotels and restaurant enjoys the new availability of opportunity for deliver the food to their customer without extra efforts, the increased sales through FOMA services are engaged the hotels are busy to prepare the food all the times and the wastage food is reduced due unlimited support from the customer. The IT and ITES based companies situated in Chennai working of round the clock, so the desired food demand of those people served by this FOMA services irrespective of the time concern. Earlier they forced to be eating at food court present at the premises itself so identifying desired and healthy food is impossible.

\section{REVIEW OF LITERATURE}

Meehee Cho, Mark A. Bonn and Jun (Justin) Li (2018) studies the Perception differences among single-Person and multiple-Person household users of food delivery app services in china. To determine this the authors tried to explore the five quality attributes such as convenience, design, trustworthiness, price and user-perceived value, among this user trustworthiness is important criteria for food delivery app services, however single-person households consider important on various food choices, price and trustworthiness whereas multi-person households gives important to design, convenience and trustworthiness.

Adithya \& et al., (2018) made a study on online food ordering system. The online food ordering system is needed because of recent changes in the food industry and increasing use of internet. The objective of the study to develop a reliable, convenient and accurate food ordering system is considered and also the customer service. The implementation of the system application is done in Java, jquery, HTML and the datasets are stored in MySQL database. The development made by a hybrid android application using Cordova. The author found that the application will made a ease order and track the food.

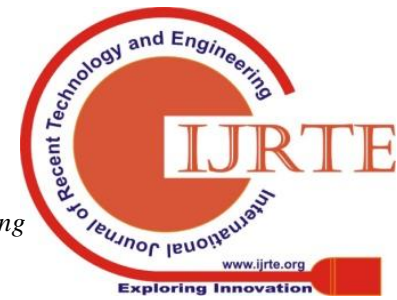


Anjali Baranwal (2018) made a research on an innovative approach for online food order management system with an objective of how the restaurant owners and staffs managing the orders from an online. A questionnaire is collected from the restaurant owners as well as from the working staff in the hotel industries. The suggestions given by the author is an android based operating system is an open source operating platform with programmers aiming to make it better. Thus, the proposed system would attract customers and also adds to the efficiency for maintain the restaurant ordering.

Rachmat Auli (2017) wanted to find the mechanism of food ordering in a restaurant using android technology. The purpose is to make simple the processing of the food order as well as speed up the ordering meals in the android application. The methodology used in this system id SDLC (software development life cycle), has four phases are planning, analysis, design, and implementation. He founded that the application is to replace the use of paper and pen to digital devices when making orders and this can reduce the level of errors that occur in the kitchen at the time of processing the consumer's order.

Aniruddha Deshpande (2016) made an analysis of the way of ZOMATO has scaled up its operations, expanded its business into various countries and also plan to find out their SWOT analysis. The findings are it has a strength of world wide spread across 22 countries with 2000 plus Zomans from 65 nationalities and revenue growth Rs.11.4 Crore in 2012-13 and Rs.96.7 crore in 2014-15. The weakness with expansion to various countries, it how has competitors. The opportunities of Zomato is new/emerging markets, cashless transaction to attract their customers etc, the threats are aggressive expansion in a huge market landscape which may not be a bad thing but when this comes at a cost of losing out domestic ground, it may not be the best thing to do.

\section{OBJECTIVES OF THE STUDY}

1. To study the demographic profiles of the respondents in Chennai city.

2. To understand the customer perception towards food ordering mobile application usage.

3. To explore the different types of food ordering mobile application users in the study area.

\section{RESEARCH METHODOLOGY}

The present study is exploratory and empirical in nature and adopted survey method for the findings. The structured questionnaire was used to gather the perception of customers with respect to online food ordering mobile applications in Chennai city. The non-probability convenience sampling technique was adopted to collect samples of 245 from FOMA users were finalised for this empirical investigation.

\section{RESULTS AND DISCUSSION}

The data collected were subjected to data analysis using SPSS version 23.0 and statistical tools such as, percentage analysis, descriptive analysis, factor analysis, cluster analysis and discriminant analysis has been applied to draw meaningful answers to the research questions.
Table 1: Demographic Characteristics of the Respondents

\begin{tabular}{|c|c|c|}
\hline $\begin{array}{l}\text { Demographic Characteristics }(N= \\
\text { 245) }\end{array}$ & Frequency & $\begin{array}{l}\text { Percentage } \\
\quad(\%)\end{array}$ \\
\hline \multicolumn{3}{|l|}{ Age (in Years) } \\
\hline Below 20 & 30 & 12.2 \\
\hline Between 21 to 25 & 99 & 40.4 \\
\hline Between 26 to 30 & 40 & 16.3 \\
\hline Above 30 & 76 & 31.0 \\
\hline \multicolumn{3}{|l|}{ Gender } \\
\hline Male & 140 & 57.1 \\
\hline Female & 105 & 42.9 \\
\hline \multicolumn{3}{|l|}{ Educational Qualification } \\
\hline Upto $12^{\text {th }}$ & 35 & 14.3 \\
\hline UG & 87 & 35.5 \\
\hline PG & 87 & 35.5 \\
\hline Professional Degree & 20 & 8.2 \\
\hline Diploma & 16 & 6.5 \\
\hline \multicolumn{3}{|l|}{ Occupation } \\
\hline Student & 104 & 42.4 \\
\hline Private Employee & 85 & 34.7 \\
\hline Government Employee & 25 & 10.2 \\
\hline Business Man & 15 & 6.1 \\
\hline Professional & 16 & 6.5 \\
\hline \multicolumn{3}{|l|}{ Family Type } \\
\hline Nuclear Family & 128 & 52.2 \\
\hline Joint Family & 117 & 47.8 \\
\hline \multicolumn{3}{|l|}{ Marital Status } \\
\hline Married & 106 & 43.3 \\
\hline Unmarried & 139 & 56.7 \\
\hline \multicolumn{3}{|l|}{ Monthly Income Level } \\
\hline Below 20K & 83 & 33.9 \\
\hline $20 \mathrm{k}$ to $30 \mathrm{k}$ & 82 & 33.5 \\
\hline $30 \mathrm{k}$ to $40 \mathrm{k}$ & 44 & 18.0 \\
\hline 40k and above & 36 & 14.6 \\
\hline
\end{tabular}

Table 1 indicates that sizeable of the respondents are belongs to an age group of 21 years to 25 years (40.4\%), followed by age group of Above 30 Years(31.0\%), 26 years to 30 years $(16.3 \%)$ and less than 20 years $(12.2 \%)$ respectively. Majority of the respondents are Male $(57.1 \%)$ followed by female respondents $(42.9 \%)$. Sizable portion of the respondents are graduates $(35.5 \%)$ followed by post graduates $(35.5 \%)$, 
school educated (14.3\%), professional Degree (8.2\%) and Diploma $(6.5 \%)$. Sizeable portion of the respondents are Students $(42.4 \%)$ followed by Private employee $(34.7 \%)$, Government employee (10.2\%), Professionals (6.5\%) and Business Man (6.1\%). Majority of the respondents are belongs to nuclear families $(52.2 \%)$ followed by joint family (47.8\%). Majority of the respondents are unmarried (56.7\%) followed by married respondents $(47.8 \%)$. Maximum number of the respondents are earning monthly income of Rs. Below 20,000 (33.9\%) followed by income group of Rs. 20,000 to Rs. 30,000 (33.5\%), Rs. 30,000 to Rs.40,000 (18 $\%)$ and above $40,000(14.6 \%)$.

Table 2: Mean Based Ranking of Preferred FOMA Service Provider

\begin{tabular}{|c|l|c|c|c|}
\hline $\begin{array}{c}\text { Sl. } \\
\text { No }\end{array}$ & $\begin{array}{c}\text { Leading FOMA } \\
\text { Service Provider }\end{array}$ & Mean & SD & Rank \\
\hline 1 & Food Panda & 2.16 & 1.461 & 4 \\
\hline 2 & Swiggy & 2.93 & 1.517 & 1 \\
\hline 3 & Zomato & 2.36 & 1.386 & 3 \\
\hline 4 & Uber Eats & 2.84 & 1.591 & 2 \\
\hline
\end{tabular}

Table 2 show the Most Prefered FOMA service provider is Swiggy (Ranked 1st Mean=2.93) followed by the Uber Eats $($ Ranked 2, $($ Mean=2.84)), Zomato $($ Ranked 3rd $($ Mean = 2.36)) and Food Panda (Ranked 4th (Mean= 2.16)).

\section{A. Factorisation of Perception Towards Food Ordering Mobile App Services (FOMA) Variables}

The Perception towards FOMA services are mainly depends on several specific services offered by them. Factor analysis (FA) aims to explore the underlying dimensions that explain the pattern of correlations within a set of observed variables. Factor analysis is the data reduction technique commonly used to reduce set of observed variables in meaningful and manageable factors that explain most of the observed variance. A factor analysis has been administered to 20 FOMA services variables to understand the underlying latent dominant dimensions of them. The extraction method of Principal Component Analysis (PCA) with Varimax rotation and Kaiser Normalization method has been applied to extract the meaningful and manageable dimensions. The results are shown in Table 3.

Table 3: Factorization of Food Ordering Mobile Application (FOMA) Variables

\begin{tabular}{|c|c|c|c|c|c|}
\hline $\begin{array}{c}\text { Dimension } \\
\mathrm{s}\end{array}$ & Items & $\begin{array}{l}\text { Mean } \\
\text { (SD) }\end{array}$ & Communalities & $\begin{array}{c}\text { Variance } \\
\text { (Eigen } \\
\text { Value) }\end{array}$ & Loadings \\
\hline \multirow{3}{*}{$\begin{array}{l}\text { Reliable } \\
\text { Service } \\
\text { Factor }\end{array}$} & $\begin{array}{l}\text { Convenient } \\
\text { payment } \\
\text { option }\end{array}$ & $\begin{array}{c}4.05 \\
(.997)\end{array}$ & 0.667 & \multirow{3}{*}{$\begin{array}{c}9.888 \\
(1.978)\end{array}$} & 0.758 \\
\hline & $\begin{array}{l}\text { Accuracy in } \\
\text { order delivery }\end{array}$ & $\begin{array}{c}3.62 \\
(1.126)\end{array}$ & 0.629 & & 0.652 \\
\hline & $\begin{array}{l}\text { Reasonable } \\
\text { Pricing }\end{array}$ & $\begin{array}{c}3.74 \\
(1.115)\end{array}$ & 0.456 & & 0.546 \\
\hline
\end{tabular}

\begin{tabular}{|c|c|c|c|c|c|}
\hline $\begin{array}{c}\text { Dimension } \\
\mathrm{s}\end{array}$ & Items & $\begin{array}{l}\text { Mean } \\
\text { (SD) }\end{array}$ & Communalities & \begin{tabular}{|c|} 
Variance \\
(Eigen \\
Value)
\end{tabular} & Loadings \\
\hline \multirow{3}{*}{$\begin{array}{l}\text { Navigation } \\
\text { al Factor }\end{array}$} & $\begin{array}{l}\text { Un } \\
\text { interpreted } \\
\text { App } \\
\text { performance }\end{array}$ & $\begin{array}{c}3.54 \\
(1.185)\end{array}$ & 0.660 & \multirow{3}{*}{$\begin{array}{c}9.175 \\
(1.835)\end{array}$} & 0.766 \\
\hline & $\begin{array}{l}\text { Periodical } \\
\text { offers/Discoun } \\
\text { ts provided }\end{array}$ & $\begin{array}{c}3.71 \\
(1.168)\end{array}$ & 0.516 & & 0.613 \\
\hline & $\begin{array}{l}\text { Easy to Track } \\
\text { the order }\end{array}$ & $\begin{array}{c}3.71 \\
(1.185)\end{array}$ & 0.695 & & 0.601 \\
\hline \multirow{2}{*}{$\begin{array}{l}\text { Information } \\
\text { Design } \\
\text { Factor }\end{array}$} & \begin{tabular}{|l} 
Description \\
about the \\
content of food \\
is clearly \\
Shown
\end{tabular} & $\begin{array}{c}3.55 \\
(1.018)\end{array}$ & 0.582 & \multirow{2}{*}{$\begin{array}{c}8.574 \\
(1.715)\end{array}$} & 0.731 \\
\hline & \begin{tabular}{|l} 
Image \\
Representatio \\
$\mathrm{n}$ of Menu is \\
Genuine
\end{tabular} & $\begin{array}{c}3.58 \\
(1.234)\end{array}$ & 0.605 & & 0.671 \\
\hline \multirow{3}{*}{$\begin{array}{c}\text { Authenticat } \\
\text { ed Service } \\
\text { Factor }\end{array}$} & $\begin{array}{l}\text { No minimum } \\
\text { order Value }\end{array}$ & $\begin{array}{c}3.49 \\
(1.263)\end{array}$ & 0.561 & \multirow{3}{*}{$\begin{array}{c}8.432 \\
(1.686)\end{array}$} & 0.658 \\
\hline & $\begin{array}{l}\text { Coupon is not } \\
\text { working as per } \\
\text { they promised }\end{array}$ & $\begin{array}{c}3.34 \\
(1.213)\end{array}$ & 0.594 & & 0.594 \\
\hline & \begin{tabular}{|l|} 
Original \\
Bills/Receipts \\
From the \\
Restaurant
\end{tabular} & $\begin{array}{c}3.67 \\
(1.170)\end{array}$ & 0.508 & & 0.549 \\
\hline \multirow{2}{*}{$\begin{array}{l}\text { Single } \\
\text { Window } \\
\text { Factor }\end{array}$} & $\begin{array}{l}\text { It provides the } \\
\text { verities of food } \\
\text { menu }\end{array}$ & $\begin{array}{c}3.89 \\
(1.010)\end{array}$ & 0.614 & \multirow{2}{*}{$\begin{array}{c}8.256 \\
(1.651)\end{array}$} & 0.723 \\
\hline & \begin{tabular}{|l} 
It Listed wide \\
variety of \\
Hotel/ \\
Restaurant \\
\end{tabular} & $\begin{array}{c}4.45 \\
(0.832)\end{array}$ & 0.591 & & 0.651 \\
\hline \multirow[t]{2}{*}{$\begin{array}{l}\text { Grievance } \\
\text { Factor }\end{array}$} & $\begin{array}{l}\text { After } \\
\text { Receiving the } \\
\text { order from the } \\
\text { restaurant the } \\
\text { delivery } \\
\text { person takes } \\
\text { more time to } \\
\text { deliver }\end{array}$ & $\begin{array}{c}3.58 \\
(1.078)\end{array}$ & 0.676 & \multirow[t]{2}{*}{$\begin{array}{c}7.512 \\
(1.502)\end{array}$} & 0.770 \\
\hline & \begin{tabular}{|lr} 
Feedback & \\
option is really \\
helpful r \\
show & my \\
feelings &
\end{tabular} & $\begin{array}{c}3.41 \\
(1.217)\end{array}$ & 0.571 & & 0.658 \\
\hline \multirow[b]{2}{*}{$\begin{array}{l}\text { Firmness } \\
\text { Factor }\end{array}$} & $\begin{array}{ll}\text { Hidden } & \text { cost } \\
\text { Charges } & \end{array}$ & $\begin{array}{c}3.51 \\
(1.096)\end{array}$ & 0.726 & \multirow[b]{2}{*}{$\begin{array}{c}6.924 \\
(1.385)\end{array}$} & 0.809 \\
\hline & $\begin{array}{l}\text { Refund } \\
\text { promptly done } \\
\text { While cancel } \\
\text { the order }\end{array}$ & $\begin{array}{c}3.49 \\
(1.144)\end{array}$ & 0.632 & & 0.743 \\
\hline
\end{tabular}

Total Variance $=58.761 \%$ Meaningfully extracted 7 Dimensions Cronbach's Alpha Value $=0.804$ of 20 Items

KMO and Bartlett's Test: Kaiser-Meyer-Olkin Measure of Sampling Adequacy. $=0.757$

(Bartlett's Test of Sphericity Approx. Chi-Square: 920.267; df: 190; Sig. = $0.000)$

Table 3 indicates that with lower standard deviation values, the mean values of the FOMA are the robust measure of them and FOMA variables have Communalities ranging from 0.516 to 0.852 . 
Therefore, those FOMA variables are fit for factorization. The Kaiser-Meyer-Olkin Measure of Sampling Adequacy (KMO-MSA) test the MSA value of 0.757 (nearer to One) and in Bartlett's Test of Sphericity the Chi-square value of 920.267 at 190 degrees of freedom with probability value of less than 0.001 indicates that the factor analysis can be applied to 20 FOMA variables.

Table 3 reveals that 20 FOMA variables have been significantly grouped into five independent dominant factors which explain $58.761 \%$ of variance in them. The most dominant factor explains $9.88 \%$ variance in the FOMA variables and it contains 3FOMA variables of convenient payment option, Accuracy in order delivery and Reasonable Pricing in the order of importance of their relative correlations with it and therefore, it is labelled as Reliable Service Factor (RSF). The second most dominant factor explains $9.175 \%$ of the variance in FOMA variables and it is made of 3 FOMA variables of Un - interpreted App performance, Periodical offers/Discounts provided and Easy to Track the order in the order of importance of their relative correlation with it and therefore, it is named as Navigational Factor (NF). The third most dominant factor explains $8.574 \%$ of the variance in the FOMA variables and it consist of 2FOMA variables of Description about the content of food is clearly Shown and Image Representation of Menu is Genuine in the order of relative correlations with it and therefore, it is labelled as Information Design Factor (IDF). The fourth most dominant factor explains $8.432 \%$ of the variance in the FOMA variables and it contains of 3FOMA variables of No minimum order Value, Coupon is not working as per they promised and Original Bills/Receipts From the Restaurant in the order of relative correlations with it and therefore, it is named as Authenticated Service Factor (ASF). The fifth most dominant factor explains $8.256 \%$ of the variance in the FOMA variables and it consist of 2FOMA variables of it provides the verities of food menu and It Listed wide variety of Hotel/ Restaurant in the order of relative correlations with it and therefore, it is labelled as Single Window Factor (SWF). The sixth most dominant factor explains $8.256 \%$ of the variance in the FOMA variables and it consist of 2FOMA variables of After Receiving the order from the restaurant the delivery person takes more time to deliver Feedback option is really helpful to show my feelings in the order of relative correlations with it and therefore, it is labelled as Grievance Factor (GF). The Seventh most dominant factor explains $6.924 \%$ of the variance in the FOMA variables and it consist of 2 FOMA variables of Hidden cost Charges and Refund promptly done while cancel the order in the order of relative correlations with it and therefore, it is labelled as Firmness Factor (FF). Thus, SEVEN independent, meaningful and manageable factors have been extracted out of 20 FOMA variables of which the Reliable Service Factor is the most dominant one followed by Navigational Factor (NF), Information Design Factor (IDF), Authenticated Service Factor (ASF), Single Window Factor (SWF), Grievance Factor (GF) and Firmness Factor (FF) in their order of dominance.

Table 4: Descriptive Statistics of FOMA Factors

\begin{tabular}{|c|c|c|c|c|c|c|c|}
\hline & & & & & Skewness & Kurtosis \\
\cline { 5 - 8 } FOMA Factors & Mean & Median & Mode & $\begin{array}{c}\text { Std. } \\
\text { Deviation }\end{array}$ & Variance & $\begin{array}{c}\text { Statistic } \\
\text { (Std. Error = } \\
\text { 0.156) }\end{array}$ & $\begin{array}{c}\text { Statistic } \\
\text { (Std. Error = } \\
\mathbf{0 . 3 1} \text { ) }\end{array}$ \\
\hline Reliable Service Factor & 11.416 & 12 & 12 & 2.436 & 5.933 & -0.477 & 0.006 \\
\hline Navigational Factor & 10.951 & 11 & 12 & 2.707 & 7.325 & -0.429 & -0.471 \\
\hline Information Design Factor & 7.126 & 7 & 8 & 1.839 & 3.381 & -0.483 & -0.096 \\
\hline Authenticated Service Factor & 10.502 & 11 & 10 & 2.513 & 6.317 & -0.377 & -0.358 \\
\hline Single Window Factor & 8.339 & 9 & 9 & 1.492 & 2.225 & -0.849 & 0.091 \\
\hline Grievance Factor & 6.996 & 7 & 8 & 1.834 & 3.365 & -0.283 & -0.438 \\
\hline Firmness Factor & 7.000 & 7 & 6 & 1.833 & 3.361 & -0.362 & -0.295 \\
\hline
\end{tabular}

Table 4 indicates that the consumption attributes total score and its factors have robust measure of distribution since the standard deviation values are lower than the mean values. Further, the skewness and kurtosis value proves that there is a normal distribution in the measurement of variables.

\section{B. Formation of Dominant Groups for FOMA Factors}

An attempt has been made to classify all FOMA of consumers into distinctive dominant clusters significantly differentiated by 7 FOMA Factors by applying quick cluster analysis and discriminant analysis. The results are shown in the tables 4 to table 13 . 
International Journal of Recent Technology and Engineering (IJRTE) ISSN: 2277-3878, Volume-8 Issue-4S3, December 2019

Table 5: Cluster Groups of the Respondents based on the Real Estate Purchase Consideration Factors

\begin{tabular}{|c|c|c|c|c|c|c|c|c|c|c|}
\hline \multirow{2}{*}{\multicolumn{2}{|c|}{ Variables }} & \multicolumn{2}{|c|}{$\begin{array}{l}\text { Discriminant } \\
\text { Coefficient }\end{array}$} & \multicolumn{2}{|c|}{$\begin{array}{l}\text { Discriminant } \\
\text { Loadings }\end{array}$} & \multirow{2}{*}{$\begin{array}{c}\text { Cluster } \\
\text { Mean } \\
\text { Square } \\
(\mathrm{Df}=2)\end{array}$} & \multirow{2}{*}{\begin{tabular}{|c} 
Error \\
Mean \\
Square \\
(Df = 242)
\end{tabular}} & \multicolumn{3}{|c|}{ Tests of Equality of Group Means } \\
\hline & & $\begin{array}{c}\text { Function } \\
-1\end{array}$ & $\begin{array}{c}\text { Functio } \\
n-2\end{array}$ & $\begin{array}{c}\text { Functio } \\
\text { n -1 }\end{array}$ & $\begin{array}{c}\text { Functio } \\
n-2\end{array}$ & & & $\begin{array}{l}\text { Wilks' } \\
\text { Lambda }\end{array}$ & $\begin{array}{c}\text { F-Value } \\
(\mathrm{df}=\mathbf{2 , 2 4 2})\end{array}$ & Sig. \\
\hline \multicolumn{2}{|c|}{ Reliable Service Factor } & 0.422 & 0.374 & $0.681^{*}$ & 0.378 & 25.779 & 3.884 & 0.649 & 65.336 & 0.000 \\
\hline \multicolumn{2}{|c|}{ Navigational Factor } & 0.678 & 0.586 & $0.399 *$ & 0.281 & 534.973 & 2.965 & 0.401 & 180.446 & 0.000 \\
\hline \multicolumn{2}{|c|}{$\begin{array}{l}\text { Information Design } \\
\text { Factor }\end{array}$} & 0.407 & 0.240 & $0.375^{*}$ & 0.163 & 74.090 & 2.797 & 0.820 & 26.488 & 0.000 \\
\hline \multicolumn{2}{|c|}{$\begin{array}{l}\text { Authenticated Service } \\
\text { Factor }\end{array}$} & 0.159 & 0.860 & $0.272 *$ & 0.042 & 338.603 & 3.570 & 0.561 & 94.835 & 0.000 \\
\hline \multicolumn{2}{|c|}{ Single Window Factor } & 0.296 & 0.297 & $0.259 *$ & 0.173 & 82.617 & 1.561 & 0.696 & 52.941 & 0.000 \\
\hline \multicolumn{2}{|c|}{ Grievance Factor } & 0.262 & 0.151 & $0.174 *$ & 0.107 & 75.248 & 2.771 & 0.817 & 27.159 & 0.000 \\
\hline \multicolumn{2}{|c|}{ Firmness Factor } & 0.142 & 0.076 & 0.351 & 0.685 & 36.983 & 3.083 & 0.910 & 11.997 & 0.000 \\
\hline \multicolumn{11}{|c|}{ (Test of Function -1 through 2: Wilks' Lambda $=0.134 ;$ Chi-Square $=480.577, d f=14 ;$ Sig. $=0.000$} \\
\hline \multicolumn{11}{|c|}{ Function -2: Wilks Lamba $=0.528 ;$ Chi-square $=152.783, d f=6$, Sig. $=0.000)$} \\
\hline \multicolumn{11}{|c|}{ Function -1 : Eigen Value $=2.941 ;$ Variance $=76.7 \% ;$ Canonical Correlation $=0.864$} \\
\hline \multicolumn{11}{|c|}{ Function -2 : Eigen Value $=0.895 ;$ Variance $=23.3 \% ;$ Canonical Correlation $=0.687$} \\
\hline \multicolumn{11}{|c|}{ Accuracy of Respondents Classification } \\
\hline & & & & & & & Predicte & Group Membe & rship & \\
\hline & & & Ciust & 1 1 vuntod & Jit case & & roup - 1 & Group - 2 & Group - 3 & Total \\
\hline & & & oup - 1 & & & & 80 & 1 & 1 & 82 \\
\hline & Count & & oup - 2 & & & & 2 & 102 & 0 & 104 \\
\hline & & & oup - 3 & & & & 1 & 1 & 57 & 59 \\
\hline 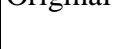 & & & oup - 1 & & & & 32.6 & 0.4 & 0.4 & 33.1 \\
\hline & $\%$ & & oup - 2 & & & & 0.8 & 42 & 0 & 42.8 \\
\hline & & & oup -3 & & & & 0.4 & 0.4 & 23.3 & 24.1 \\
\hline
\end{tabular}

\section{Figure 1}

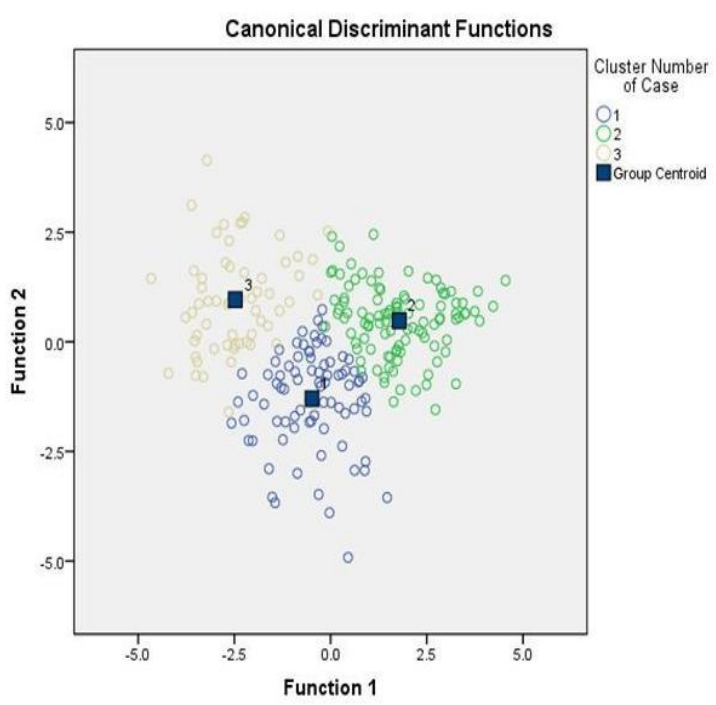

Table 5 and Figure 1 show that 3 dominant clusters have been formed significantly differentiated by both two FOMA factors. Of the two discriminant functions, the most discriminant function 1 with Eigen value of 2.941 and Canonical correlation of 0.864 and also with Wilk's Lambda value of .134 and the Chi-Sqaure value of 480.577 at df14 and 0.000 level of significance, explains $76.7 \%$ variance in the differentiation. Reliable service factor, navigational factor, information design factor, authenticated service factor, single window factor and grievance factor. Over all it has been named as Accessibility Discriminant Function. The Second most discriminant function 2 with Eigen Value of .895 and Canonical correlation of 0.687 and also with Wilk's Lambda value of 0.528 and Chi-Square value of 152.783 at $6 \mathrm{df}$ and 0.000 level of significance, explains $23.3 \%$ of variance in differentiation. In it, the most dominating differentiating factor is Firmness factor alone so it is named as Firmness Discriminant Function. 
The table 4 shows that the first cluster formed has 82 respondents constituting of $33.5 \%$ of the 245 total respondents covered in the study. The second and the third clusters have 104 and 59respondents comprising of $42.44 \%$ and $24.08 \%$ of total respondents respectively. The table 13 reveals that $96.6 \%$ of such classification is correct. Thus, all 245 respondents have been classified into 3 dominant FOMA groups of the Moderate Perception Group, Higher Perception Group and Lesser perception Group significantly differentiated by both 7 Food ordering Mobile app Factors along with 2 discriminant functions of Accessibility and Firmness.

\section{IMPLICATIONS AND CONCLUSION}

This exploratory study was aimed to explore the dominant dimensions and dominant groups of online food ordering service users in the Chennai city. The results indicates that seven important dimensions has been explored such as, Reliable Service Factor, Navigational Factor (NF), Information Design Factor (IDF), Authenticated Service Factor (ASF), Single Window Factor (SWF), Grievance Factor (GF) and Firmness Factor (FF) and all the online food ordering service users were significantly grouped into three groups namely, higher perception users, moderate perception users and lesser perception users. This present study brings out that usage of online food services with the help of mobile applications are drastically and constantly increasing due to technological and socio-economic growth among the people. So, online food ordering service providers are suggested to attract more food suppliers in nook and corner of the city to attract and serve more customers in near future to meet the expected increase in the demand.

\section{REFERENCES}

1. Cho, M., Bonn, M. A., \& Li, J. J. (2019). Differences in perceptions about food delivery apps between single-person and multi-person households. International Journal of Hospitality Management, 77, 108-116.

2. R., Adithya \& Singh, Abhishek \& Pathan, Salma \& Kanade, Vaishnav. (2017). Online Food Ordering System. International Journal of Computer Applications. 180. 22-24. 10.5120/ijca2017916046.

3. Baranwal, A., Srivastava, A., \& Rani, B. (2019). An Innovative Approach for Online Food Order Management System. Global Journal of Computer Science and Technology.

4. Aulia, R., Zakir, A., Dafitri, H., \& Siregar, D. (2017, December) Mechanism of Food Ordering in A Restaurant Using Android Technology. In Journal of Physics Conference Series (Vol. 930, No. 1).

5. Aniruddha Deshpande (2016). Zomato - Market and Consumer Analysis. Gurgaon, Haryana, India, 1(6).

\section{AUTHORS PROFILE}

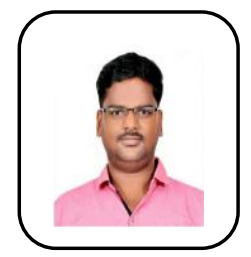

M. Shanmugavel was Research Scholar of the Department of Commerce, University of Madras. He is qualified both UGC-NET and TN-SET in both Commerce as well as Management. He had Awarded UGC-RGN-SRF and Working on the PhD theme of Merger and Acquisition. Fascinated Research area is Finance, Marketing and Human Resources Management. Published numerous articles in the national and international conferences and published various researcher papers in UGC care listed journals. He was Post-Graduated Commerce student from Guru Nanak College and completed his Pre-Doctoral research programme in Department of Commerce, University of Madras, Chennai.

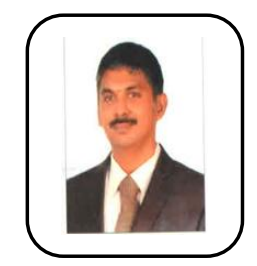

Dr. B. Devamaindhan is an Associate Professor of Management Studies IDE University of Madras, having a teaching experience of over 22 years, specialized in the Research and Subject area of Marketing and Human Resources. He is a Chairman, Board of Studies in Management (IDE), University of Madras and member in various BOS of various colleges and universities across the Management disciplinary. Nodal Officer, All India Survey on Higher Education for the University of Madras from March 2016 to till date, Director, Network, University of Madras from May 2014 to 2017 and Coordinator, Pan African E-Network Project, University of Madras from October 2010 to March 2014. He has written \& Edited many books for the University of Madras, Tamilnadu Open University, Tamilnadu Sports University, Chennai and Annamalai University, Chitambaram. 